\title{
Intravenous acetaminophen in combination with remifentanil / nitrous oxide on post- tonsillectomy nausea-vomiting and pain in children-a randomised controlled trial
}

\section{Cocuklarda tonsillektomi sonrası bulantı, kusma ve ağrı üzerine remifentanil/nitröz oksitle kombine intravenöz asetaminofen}

\author{
*Başak Akça ${ }^{1}$, Aysun Ankay Yılbaş ${ }^{1}$, Nalan Çelebi ${ }^{2}$ \\ ${ }^{1}$ Department of Anesthesiology and Reanimation, Hacettepe University School of Medicine, Ankara, Turkey \\ ${ }^{2}$ Department of Anesthesiology and Reanimation Hacettepe University School of Medicine,Ankara, Turkey \\ Corresponding author: Dr. Başak Kantar, Anesteziyoloji ve Reanimasyon Anabilim Dalı, Hacettepe Üniversitesi Tıp \\ Fakültesi, TR 06100, Ankara, Turkey. \\ E-mail: basak_kantar@yahoo.com \\ Received/Accepted: February 13, 2015/September 01, 2015 \\ Conflict of interest: There is not a conflict of interest.
}

\begin{abstract}
SUMMARY
Objective: Many anesthesiologists have quit using nitrous oxide in their daily practice because of its side effects and also the introduction of short-acting opioids such as remifentanil. Our aim is to compare the effects of intraoperative remifentanil vs nitrous oxide in combination with iv acetaminophen on post-tonsillectomy pain in children

Method: Sixty-eight, pediatric patients undergoing adenonsillectomy operations were randomized into two groups of thirty-four each. General anaesthesia was induced by inhalation of sevoflurane $(8 \%)$ in both groups. The nitrous oxide group (group I) received sevoflurane at an end-tidal conentration of 1.5-2, delivered with $70 \%$ nitrous oxide in oxygen. The remifentanil group (group II) also received sevoflurane in the same way but delivered in an oxygen-air gas mixture. Group II also received an intravenous (i.v.) infusion of remifentanil at $0.1-0.3 \mu \mathrm{g} / \mathrm{kg}-1 \mathrm{~min}-1$. Both of the groups received i.v. acetaminophen infusions before surgical incision. Pain scores in the PACU and during the first $24 \mathrm{~h}$ were assessed.

Results: Demographics were similar among the groups. Twenty three patients in group I and 7 patients in group II have required rescue analgesia and time to first analgesia was longer in group II. Thirty-three $(97.1 \%)$ patients in group I and $20(58.8 \%)$ patients in group II needed analgesics at home. Pain scores in the PACU and at 24 . hr were significantly lower in group II.

Conclusion: Combination of i.v. acetaminophen with remifentanil rather than nitrous oxide seems to be more suitable for outpatient adenotonsillectomy operation.
\end{abstract}

Keywords: Remifentanil, nitrous oxide, adenotonsillectomy surgery, pediatric anesthesia

\section{ÖZET}

Amaç: Birçok anestezist hem yan etki profili nedeniyle hem de kisa etkili bir opioid olan remifentanilin kullanıma girmesiyle günlük pratiklerinde nitröz oksit kullanımından vazgeçmişlerdir. $\mathrm{Bu}$ çalışmada amacımız, intraoperatif dönemde intravenöz (i.v.) yoldan uygulanan parasetamol beraberinde nitröz oksit veya remifentanilin çocuk hastalarda tonsillektomi sonrası ağriya etkisinin incelenmesidir.

Method: Adenotonsillektomi planıla cerrahiye alınan 68 pediyatrik yaş grubunda hasta 34 hastalık iki gruba ayrıldı. Her iki grupta da \%8 sevofluran ile indüksiyon yapıldı. Nitröz oksit grubunda (Grup 1) \%30/70 oksijen-nitröz oksit karışımı içinde sevofluran konsantrasyonu \% 1,5-2 olacak şekilde idame edildi. Remifentanil grubunda ise (Grup 2) \%30/70 oksijen-hava karışımı içinde sevofluran konsantrasyonu \%1,5-2 olacak şekilde idame edildi. Grup 2 hastalarında i.v. remifentanil infüzyonu $(0.1-0.3 \mu \mathrm{g} / \mathrm{kg} / \mathrm{dk})$ yapıldı. Her iki grupta da cerrahi insizyon başlamadan 
önce i.v. asetaminofen $(15 \mathrm{mg} / \mathrm{kg})$ uygulandı. Ayılma ünitesinde ve 24. saatte ağr1 skorlar1 değerlendirildi.

Bulgular: Demografik veriler iki grupta da benzerdi. Grup 1'de 23 hastanın Grup 2'de ise 7 hastanın ek analjezik ihtiyacı oldu ve operasyon çıkışından ilk analjezik ihtiyacına kadar geçen süre Grup 2'de daha uzundu. Grup 1'de 33 hasta (\%97,1), Grup 2'de ise 20 hastanın (\%58,8) eve taburculuğunda analjezi ihtiyacı oldu. Grup 2'de ayılma ünitesinde ve postoperatif 24. saatte telefonla aranarak değerlendirilen ağrı skorları belirgin olarak daha düşüktü.

Sonuç: Günübirlik cerrahi olarak yapılan adenotonsillektomi operasyonlarında i.v. asetaminofen ve remifentanil kombinasyonunun nitröz oksite göre daha uygun bir tercih olduğu kanısındayı.

Anahtar sözcükler: Remifentanil, nitröz oksit, adenotonsillektomi cerrahisi, pediatrik anestezi

\section{INTRODUCTION}

Nitrous oxide, in conjunction with oxygen, is generally used as a carrier gas for volatile inhalational anesthetic agents. It has the benefit of supplying analgesia and reducing the minimal anesthetic concentration of the volatile anesthetics, and its low blood/gas solubility enables a reasonably fast onset and offset. However, it is increasingly documented to be associated with a number of unwanted effects, such as pollution, neurotoxicity, and megaloblastic anemia ${ }^{1-3}$ and an established risk factor for postoperative nausea and vomiting ${ }^{4}$. Many anesthesiologists have stopped using nitrous oxide in their daily practice because of concern about its adverse effects ${ }^{5-7}$. Remifentanil, a potent, ultra short-acting opioid, used as an analgesic agent during induction and maintenance of anaesthesia, may be preferred without the above mentioned side effects of nitrous oxide. Different from the other opioids, it can be given in very high doses during surgery with a predictable and rapid recovery that is relatively independent of the dose with little risk of respiratory depression ${ }^{8-9}$.

The aim of our study is to compare the effects of intraoperative remifentanil vs nitrous oxide in combination with iv acetaminophen on post-tonsillectomy pain in children.

\section{MATERIAL AND METHODS}

In this randomized, prospective, doubleblinded study after approval from our institutional ethics committee (Hacettepe University, Ankara Turkey) and obtaining a written informed consent by the parents of the paediatric patients, we studied sixtyeight ASA I pediatric patients undergoing adenonsillectomy operations. Patients with known allergy to drugs used, a history of allergy, asthma, cardiovascular or neurologic disease, mental retardation, malignant hyperthermia risk and growth retardation were excluded.

The patients were randomized into two groups of thirty-four each. Randomization was based on computer-generated codes maintained in sequentially numbered, opaque envelopes. The exclusion criteria were psychiatric illness, pulmonary and/or cardiac disease and a history of allergy to any of the study drugs

All of the patients were premedicated with midazolam intranasally $(0.5 \mathrm{mg} / \mathrm{kg}) \max$ $15 \mathrm{mg}, 15 \mathrm{~min}$ prior to surgery. All patients were monitored in a standard manner and $\mathrm{SpO}_{2}$, systolic arterial pressure and heart rates were recorded every 5 minutes. Both groups received general anaesthesia, which was induced by inhalation of sevoflurane $(8 \%)$. The envelopes were opened after induction of general anaesthesia. The nitrous oxide group (Group 1) received sevoflurane at an end-tidal concentration of 1.5-2\% (according to clinical requirement), delivered with $70 \%$ nitrous oxide in oxygen. The remifentanil group (Group 2) also received sevoflurane in the same way but delivered in an oxygen-air gas mixture. This group of patients also received an intravenous infusion of remifentanil at $0.1-0.3 \mu \mathrm{g} / \mathrm{kg}-1 \mathrm{~min}-1$. Both of the groups received iv. acetaminophen infusions $(15 \mathrm{mg} / \mathrm{kg})$ after placing an intravenous catheter in $20 \mathrm{~min}$ and $1.5 \mu \mathrm{g} / \mathrm{kg}$ fentanyl was administered to both groups intravenously before surgical incision. The dose of anesthetic drugs was adjusted when insufficient anaesthesia was suspected. Insufficient anaesthesia was suspected when a heart rate exceeding pre-induction values by $15 \%$ and/or a systolic blood pressure exceeding baseline values by $20 \%$ 
for at least $1 \mathrm{~min}$, presence of patient movement, coughing, tearing, or sweating was observed. Rocuronium $0.5 \mathrm{mg} / \mathrm{kg}-1$ intravenously was used to facilitate the endotracheal intubation and before surgical manipulation, ondansetron $(0.1 \mathrm{mg} / \mathrm{kg}$, maximal dose of $4 \mathrm{mg}$ ) and dexamethasone $(0.25-0.5 \mathrm{mg} / \mathrm{kg}$, maximal dose $8 \mathrm{mg}$ ) were administered IV to prevent postoperative nausea and vomiting. At the end of surgery, all anesthetic drugs were discontinued, and residual neuromuscular blockade was antagonized with $40-60 \mu \mathrm{g} / \mathrm{kg}$ intravenous neostigmine and $15-20 \mu \mathrm{g} / \mathrm{kg}$ intravenous atropine. The trachea was extubated when patients responded appropriately to verbal commands, the spontaneous respiratory rate exceeded 10 breaths/min, and there was full return of muscle strength according to peripheral nerve stimulation. Patients were excluded from the study if they had known allergy to remifentanil or intravenous acetaminophen, had abnormal preoperative renal or hepatic function, regular consumption of analgesics, hypnotics, or sedatives or had a body weight that was not within $20 \%$ of ideal.

After the extubation process the patients were brought to postanaesthesia care unit (PACU) and in the PACU pain scores (0., 15., 60. min ) were assessed by a PACU nurse using Modified Hannallah pain scale [observational pain scores (OPS)] (Table $1)^{10}$. Nausea, vomiting, bleeding sedation and Aldrete scores at first, 15th, 60th min postoperatively and also time to first rescue analgesia were recorded. The Aldrete score, a 10-point post anaesthesia recovery was used to determine discharge from PACU. Patients received i.v morphine (0.1 $\mathrm{mg} / \mathrm{kg}-1$ ) in the PACU for OPS scores greater than 4 , or for a continous crying for a $5 \mathrm{~min}$ period. Before the discharge, parents were given a prescription for acetaminophen to be given every $6 \mathrm{~h}$ as needed for pain. Any supplementary analgesia, nausea, vomiting, bleeding, sleep disturbance and nightmares that the child might have had were assessed during a telephone call $24 \mathrm{~h}$ later the operation. Postoperative pain during the first $24 \mathrm{~h}$ was assessed using a four-point scale. $0=$ no pain, $1=$ mild pain, $2=$ moderate pain, $3=$ severe pain. The postoperative OPS at $60 \mathrm{~min}$ was considered the primary endpoint, and was used to determine the sample size. It was calculated that sample size of 30 patients in each group would have an $80 \%$ power to detect a 20\% difference in the OPS between placebo and Group 1 and Group 2. The data for pain scores (OPS) in PACU were analyzed using a Kruskal-Wallis rank sum test. Differences among group means were compared using one-way analysis of variance (ANOVA). Categorical variables were analyzed using the chi-squared test and t-tests were used for parametric data. P-values $<0.05$ were considered significant.

\section{RESULTS}

Thirty-three males and 35 females entered the study. Data from 68 child patients were analyzed. Two patients who had asthma in their medical history were excluded from the study. There were no statistically significant differences in gender, age, weight, duration of surgery and anaesthesia and extubation times among the two groups (Table 2 ). There were no statistically significant differences between the groups in heart rate, mean arterial pressure (MAP), oxygen saturation.

Twenty three patients in Group 1 and 7 patients in Group 2 have required rescue analgesia and also time to first analgesia was longer in Group 2. Also $33(97.1 \%)$ patients in Group 1 and 20 (58.8\%) patients in Group 2 needed analgesics at home which was statistically significant (Table 3). Pain scores (OPS) in the PACU and at 24. hr were significantly lower in Group 2.

There were no significant differences between the groups as for nausea and vomiting in the first hour in PACU. Thirty-eight percent $(38.2 \%)$ of Group 1 patients, $17.6 \%$ of Group 2 patients complained of nausea and vomiting in the first $15 \mathrm{~min}$ in PACU. None of the patients required additional antiemetic in PACU but nausea and vomiting at home was significantly higher in Group 1 (44\%) wih respect to Group 2 (11\%). After 15 min in the PACU all patients had minimal or no bleeding and there were no statistically significant differences between the groups and none of the patients required reoperation for bleeding. Aldrete scores were not different be- 
tween groups. There were no significant differences in sleep patterns or dreams between the groups during the firs night. None of the parents reported any nightmares or hallucinations.

Table 1: Demographic data of the patients and duration of surgery, duration of anaesthesia and extubation time, (mean \pm SD) ( $n=$ number of patients).

\begin{tabular}{l|ll}
\hline & Group 1 & Group 2 \\
\hline & $(\mathbf{N = 3 4 )}$ & $\mathbf{( N = 3 4 )}$ \\
\hline Age (years) & $5.68 \pm 2.21$ & $6.26 \pm 2.02$ \\
Weight (kg) & $21.59 \pm 7.60$ & $21.97 \pm 5.57$ \\
Sex (F/M) & $16 / 18$ & $17 / 17$ \\
$\begin{array}{l}\text { Duration of surgery (min) } \\
\begin{array}{l}\text { Duration of anaesthesia } \\
\text { (min) }\end{array}\end{array}$ & $26.91 \pm 5.19$ & $25.38 \pm 4.69$ \\
Extubation time (min) & $6.59 \pm 2.59$ & $5.79 \pm 2.82$ \\
\hline
\end{tabular}

Table 2: Postoperative analgesic requirement at PACU, at home and time to first analgesia (mean \pm SD).

Analgesia required (number of patients at PACU)

Time to first analgesia (min)

Analgesic need at home (number of patients)

*: $\mathrm{p}=0.000 ;{ }^{\S}: \mathrm{p}=0.001{ }^{\beta}: \mathrm{p}=0.000$ compared wIth Group 1 .

$\begin{array}{ll}\text { Group } 1(\mathbf{n}=\mathbf{3 4}) & \text { Group } 2(\mathbf{n}=\mathbf{3 4}) \\ 23 & 7^{*} \\ 43.5 \pm 106.70 & 489.4 \pm 630.29^{\S} \\ 33 & 20^{\boldsymbol{\beta}}\end{array}$

Table 3: Pain scores (ops) at PACU and postoperative $24 \mathrm{hr}$. values are expressed as mean \pm SD (minimum-maximum).

\begin{tabular}{l|llll}
\hline & 0 min & $\mathbf{1 5}$ min & 60 min & 24 hour \\
\hline Group I $(\mathrm{n}=34)$ & $4.91 \pm 1.50(1-8)$ & $3.56 \pm 2.03(0-9)$ & $1.29 \pm 0.76(0-2)$ & $0.50 \pm 0.50(0-1)$ \\
Group II $(\mathrm{n}=34)$ & $3.03 \pm 1.71(0-6)^{*}$ & $2.44 \pm 1.74(0-5) \mathrm{b}$ & $0.68 \pm 1.00(0-4) \mathrm{c}$ & $0.24 \pm 0.49(0-2) \mathrm{d}$ \\
${ }^{*}: \mathrm{p}=0.000,{ }^{\mathbf{b}}: \mathrm{p}=0.028,{ }^{\mathbf{c}}: \mathrm{p}=0.000,{ }^{\mathrm{d}}: \mathrm{p}=0.017$ & & \\
\hline
\end{tabular}

\section{DISCUSSION}

According to our results, postoperative pain scores, the number of patients which have required rescue analgesia also the number of patients which have needed additional analgesics and experienced nausea and vomiting at home were significantly lower in remifentanil group than nitrous oxide group.

Nitrous oxide has been applied clinically in anaesthesia for more than 150 years ${ }^{5-11}$, but the low toxicity of modern anesthetic agents, the accumulating evidence about the adverse effects of nitrous oxide ${ }^{12}$ and the potential benefits of high inspired concentrations of oxygen ${ }^{13}$ provide compelling reasons to question the continued use of nitrous oxide in anesthesia. Several undesirable effects of nitrous oxide are the consequence of the irreversible inhibition of vitamin B12, which inhibits methionine synthase, folate metabolism, and deoxyribonucleic acid synthesis ${ }^{14}$. In addition, inactivation of methionine synthase is related with increased plasma homocysteine concentrations ${ }^{15}$ which may increase the risk of postoperative cardiovascular complications ${ }^{15}$. Nitrous oxide impairs cerebral blood flow activity coupling ${ }^{12}$ and worsens air space conditions (pneumothorax, air embolism) and bowel distension ${ }^{16}$. Finally, nitrous oxide is a established risk factor for postoperative nausea and vomiting ${ }^{14}$ which is a common, troublesome, and costly complication of anesthesia especially in our group of patients. The main point of our study was not the postoperative nausea and vomiting (PONV), we have found this parameter in the early postoperative period comparable between our study groups but PONV was significantly higher in nitrous oxide group at home which was a troublesome effect of nitrous oxide administration or because of higher morphine consumption in PACU.

Remifentanil hydrochloride is a new, ultrashortacting synthetic opioid that is metabolized by nonspecific plasma and tissue esterases. This short duration of action lead us to use it as a practical anesthetic for pediatric adenotonsillectomy surgery. But in a study of Davis ${ }^{17}$ and co-workers, they have used remifentanil for adenotonsillectomy operations with nitrous oxide and they have found higher postoperative pain scores in this group than the other groups and they have emphasized that better in- 
traoperative prophylactic analgesic regimens for postoperative pain control are necessary to optimize remifentanil's use as an anesthetic for children even though they have used morphine for this purpose. We have used intravenous (iv) acetaminophen as a prophylactic analgesic for the postoperative pain and the pain scores, the number of patients which required rescue analgesia were significantly lower in remifentanil group with respect to nitrous oxide group. It was also superior for this group of patients not to use morphine as a prophylactic analgesic because of adverse effects such as nausea and vomiting ${ }^{18}$. Similar to our study Atef ${ }^{19}$ and co-workers have reported that intravenous paracetamol (Perfalgan) given regularly was superior to placebo after elective tonsillectomy in adults, provided rapid effective analgesia, and was well tolerated and also in the review of Romsing ${ }^{20}$ and co-workers they have reported that 8 of the 10 studies comparing paranteral paracetamol with placebo showed imporoved pain relief after administration of parenteral propacetamol and quantitative analysis was statistically significant in favour of the treatment groups and they also reported that studies comparing parenteral with oral and oral with rectal paracetamol showed improved pain relief in parenteral and oral groups respectively although the data are much to sparse for meaningful conclusions. With respect to the abovementioned studies iv acetaminophen seems to be significant for our group of patients.

Tolerance to remifentanil was found to be related to the dose used and also the duration of opioid infusion ${ }^{21}$. Guignard and collegues reported a higher pain score and increased postoperative morphine consumption in patients having $0.3 \mu \mathrm{g} / \mathrm{kg}-1$ min-1 remifentanil infusion in a 4-h major abdominal operation compared with 0.1 $\mu \mathrm{g} / \mathrm{kg}-1 \min ^{2}{ }^{22}$. Vinik and Kissin ${ }^{23}$ have revealed that a constant $0.1 \mu \mathrm{g} / \mathrm{kg}-1 \mathrm{~min}-1$ remifentanil infusion resulted in a declining analgesic effect. In our study we substituted $70 \%$ nitrous oxide with an overall average of $0.19 \mu \mathrm{g} / \mathrm{kg}-1 \mathrm{~min}-1$ remifentanil infusion for adenotonsillectomy surgery with a mean duration of $25 \mathrm{~min}$. We did not observe any hyperalgesic effect of remifentanil. The most likely explanation for the greater analgesic requirement in the nitrous oxide group than the remifentanil group could be the probable antihyperalgesic effect of intravenous acetaminophen. In a recent study of Koppert $^{24}$ and coworkers, they have revealed that the cyclooxygenase (COX) isozyme inhibitors parecoxib and acetaminophen reduce central hyperalgesia in humans and besides their well-known effects on inflamed peripheral tissues, inhibition of central COX provides an important mechanism of NSAID-mediated antihyperalgesia in humans. In an other recent study authors have suggested that even though the contribution to the induction and maintenance of hyperalgesia seems to be less important than that of spinal NMDA receptor activation, the opioid-induced hypersensitivity is partly mediated by spinal COX activity ${ }^{25}$.

In a recent animal study, it is reported that nitrous oxide, a common analgesic and anesthetic gas with potent NMDAantagonist properties ${ }^{26,27}$. However iv acetaminophen is a cyclooxygenase isozyme inhibitor $^{24}$. In our study, nitrous oxide group in combination with intravenous acetaminophen did not show any superior effects on postoperative pain scores, effective analgesia time and rescue analgesic consumption with respect to remifentanil group, probably due to the abovementioned different receptor activation mechanisms.

Based on these findings, combination of intravenous acetaminophen with remifentanil rather than nitrous oxide appears to be a reasonable choice for outpatient adenotonsillectomy operations.

\section{REFERENCES}

1. Louis-Ferdinand RT. Myelotoxic, neurotoxic and reproductive adverse effects of nitrous oxide. Adverse Drug React Toxicol Rev 1994; 13: 193-206.

2. Beals JK, Carter LB, JevtovicTodorovic V. Neurotoxicity of nitrous oxide and ketamine is more severe in aged than in young rat brain. Ann N Y Acad Sci 2003; 993: 123-14. 
3. Jevtovic-Todorovic V, Beals J, Benshoff N, Olney JW. Prolonged exposure to inhalational anesthetic nitrous oxide kills neurons in adult rat brain. Neuroscience 2003; 122: 609-16.

4. Apfel CC, Bacher A, Biedler A, Danner K, Danzeisen O, Eberhart LH. [A factorial trial of six interventions for the prevention of postoperative nausea and vomiting]. Anaesthesist 2005; 54: 201-9.

5. Schwilden H, Schuttler J. 200 years of nitrous oxide (laughing gas)-and the end of an era. Anasthesiol Intensivmed Notfallmed Schmerzther 2001; 36: 640.

6. Sonander H, Stenquist O, Nilsson $\mathrm{K}$. Nitrous oxide exposure during routine anaesthetic work. Measurement of biologic exposure from urine samples and technical exposure by bag sampling. Acta Anaesthesiol Scand 1985; 29: 203-8.

7. Korttila K, Pfaffli P, Linnoila M, Blomgren E, Hanninen $\mathrm{H}$, Hakkinen S. Operating room nurses' psychomotor and driving skills after occupational exposure to halothane and nitrous oxide. Acta Anaesthesiol Scand 1978; 22: 339.

8. Egan TD, Minto CF, Hermann DJ, Barr J, Muir KT, Shafer SL. Remifentanil versus alfentanil: comparative pharmacokinetics and pharmacodynamics in healthy adult male volunteers. Anesthesiology 1996; 84: 821-33.

9. Egan TD. Pharmacokinetics and pharmacodynamics of remifentanil: an update in the year 2000. Curr Opin Anaesthesiol 2000; 13: 44955.

10. Hannallah RS, Broadman LM, Belman AB, Abramowitz MD and Epstein BS. Comparison of caudal and ilioinguinal/iliohypogastric nerve blocks for control of postorchiopexy pain in pediatric ambulatory surgery. Anesthesiology 1987; 66: 832-4.

11. Schuttler J, Schwilden H. [200 years of nitrous oxide-at the end of an era?]. Anasthesiol Intensivmed Notfallmed Schmerzther 2001; 36: 640.

12. Kaisti KK, Langsjo JW, Aalto S, Oikonen V, Sipila H, Teras M. Effects of sevoflurane, propofol, and adjunct nitrous oxide on regional cerebral blood flow, oxygen consumption, and blood volume in humans. Anesthesiology 2003; 99: 603-13.

13. Belda FJ, Aguilera L, Garcia de la Asuncion J, Alberti J, Vicenti R, Ferrandiz L. Supplemental perioperative oxygen and the risk of surgical wound infection: a randomized controlled trial. Jama 2005; 294: 2035-42.

14. Myles PS, Leslie K, Chan MT, Forbes A, Paech MJ, Peyton P. Avoidance of nitrous oxide for patients undergoing major surgery: a randomized controlled trial. Anesthesiology 2007; 107: 221-31.

15. Badner NH, Beattie WS, Freeman $D$, Spence JD. Nitrous oxideinduced increased homocysteine concentrations are associated with increased postoperative myocardial ischemia in patients undergoing carotid endarterectomy. Anesth Analg 2000; 91: 1073-9.

16. Myles PS, Leslie K, Silbert B, Paech MJ and Peyton P. A review of the risks and benefits of nitrous oxide in current anaesthetic practice. Anaesth Intensive Care 2004; 32: $165-72$.

17. Davis PJ, Finkel JC, Orr RJ, Fazi L, Mulroy JJ, Woelfel SK. A randomized, double-blinded study of remifentanil versus fentanyl for tonsillectomy and adenoidectomy surgery in pediatric ambulatory surgical patients. Anesth Analg 2000; 90: 863-71.

18. White MC, Nolan JA. An evaluation of pain and postoperative nausea and vomiting following the introduction of guidelines for tonsillectomy. Paediatr Anaesth 2005; 15: 683-8.

19. Atef A, Fawaz AA. Intravenous paracetamol is highly effective in pain treatment after tonsillectomy 
in adults. Eur Arch Otorhinolaryngol 2007.

20. Romsing J, Moiniche S, Dahl JB. Rectal and parenteral paracetamol, and paracetamol in combination with NSAIDs, for postoperative analgesia. Br J Anaesth 2002; 88: 215-26.

21. Lang E, Kapila A, Shlugman D, Hoke JF, Sebel PS and Glass PS. Reduction of isoflurane minimal alveolar concentration by remifentanil. Anesthesiology 1996;

22. Guignard B, Bossard AE, Coste C, Sessler DI, Lebrault C, Alfonsi P. Acute opioid tolerance: intraoperative remifentanil increases postoperative pain and morphine requirement. Anesthesiology 2000; 93: 409-17.

23. Vinik HR, Kissin I. Rapid development of tolerance to analgesia during remifentanil infusion in humans. Anesth Analg 1998; 86: 1307-11.

24. Koppert W, Wehrfritz A, Korber N, Sittl R, Albrecht S, Schüttler J. The cyclooxygenase isozyme inhibitors parecoxib and paracetamol reduce central hyperalgesia in humans. Pain 2004; 108: 148-53.

25. Troster A, Sittl R, Singler B, Schmelz M, Schuttler J, Koppert W. Modulation of remifentanilinduced analgesia and postinfusion hyperalgesia by parecoxib in humans. Anesthesiology 2006; 105: 1016-1023.

26. Jevtovic-Todorovic V, Todorovic SM, Mennerick S, Powell S, Dikranian K, Benshaff N. Nitrous oxide (laughing gas) is an NMDA antagonist, neuroprotectant and neurotoxin. Nat Med 1998; 4: 460463.

27. Nagele P, Metz LB, Crowder CM. Nitrous oxide requires the $\mathrm{N}$ methyl-D-aspartate receptor for its action in Caenorhabditis elegans. Proc Natl Acad Sci USA 2004; 101: 8791-6. 